\title{
AUTONOMY OF TEACHER EDUCATORS TEACHING B.ED. COURSE IN DELHI
}

\author{
Zaidi R.F. ${ }^{1}$ \\ ${ }^{1}$ Jamia Millia Islamia
}

\author{
Khan W.A. ${ }^{2}$ \\ ${ }^{2}$ Jamia Millia Islamia
}

\author{
Kumar $\mathbf{R}^{3}$ \\ ${ }^{3}$ University of Manchester
}

Article DOI: https://doi.org/10.36713/epra6655

\begin{abstract}
Purpose-Teacher autonomy is one of the important research topics and has got centre place in the field of teacher education. The main purpose of autonomy is to develop the ability to organize and direct their own teaching and learning inside and outside the classroom. Hence, the present study is an attempt to explore the Autonomy of teacher educators teaching in B.Ed. colleges in Delhi concerning their gender, type of institutions and subject of teaching.

Methodology-Overall 100 teacher educators working in different types of B.Ed. colleges of Delhi were taken as sample by stratified random sampling technique. Teacher Autonomy scale (TAS) constructed by Pearson and Moomaw (2006) was used to collect data. The data was analyzed with the help of descriptive analysis and test of significance.

Findings -The result showed that moderate level of autonomy was found among teacher educators and there was statistically a significant difference for type of institutions and no difference for gender and subject of teaching was found among teacher educators of Delhi.

Significance-Teacher educators are teacher of teachers are mainly responsible to train teachers as autonomous teachers. To develop autonomy among perspective teachers, to make our teacher autonomous practitioner we should trained them in such a way that they have good chance of autonomous learning. It can only be possible if teacher educators have autonomous approach. Teacher educators autonomy should not be confined to the classroom but it also include curricular and research autonomy and teacher should have freedom to reflect and innovate to improve his teaching and learning process.
\end{abstract}

KEY WORDS: Autonomy, Teacher educators, Government B.Ed. institutions, Self-financed B.Ed. institutions

\section{INTRODUCTION}

Autonomy of Teacher Educator:

"The common presumption is that the essential learning required to prepare a productive and responsible worker for the twenty-first century must empower the individual to think as an autonomous agent in a collaborative context rather than to uncritically act on the received ideas and judgments of others. Workers will have to become autonomous, socially responsible thinkers. "(Mezirow (1993)
Teacher educator autonomy means professional independence provided by the institutions to the teacher educators to engage in self-directed teaching-learning process. It refers to the degree to which they take autonomous and independent decisions about what to teach and how to teach. The good qualities of teacher transform into their students and in this way they play an important role in nation building. According to Jyoti Shrawat(2014) "Teacher autonomy is necessary for personal and professional improvement. The studies showed that the autonomous and professional 
independent teacher teaches more effectively and conveniently than non autonomous teachers.

It is quite obvious and proved by many researches that the teacher autonomy is essential need if a teacher want to be a life-long learner, leader and decision maker (Gavrilyuk(2012). The same principle applies in case of teacher educators also. The teacher educators should work to promote their autonomy by doing some efforts like they should be expert in their field, able to observe himself/herself, co-operate with others, open for criticism and should be aware of his or her good and bad qualities.

Those teachers who are autonomous learners may be helpful in the development of autonomy in their students (Little (1995), Tort-Moloney (1997), McGrath (2000),Smith (2000), Aoki and Hamakawa (2003), Huang (2005), Vieira (2007), Smith and Erdoğan (2008) and Burkert and Schwienhorst (2008). "Teachers will hardly be prepared or able to administer autonomous learning processes in their students if their own learning is not geared to the same principles.(Leni Dam 2007). Therefore, if our aim is to make our student teachers to become autonomous teachers, autonomy should be provided to teacher educators who trained them to be autonomous teachers.

It is very hard to describe teacher autonomy from multidimensional perspectives (Aoki, 2000; Einoff, 2000; Huang,2005; Smith,2008). Thavenius(1999) defines teacher autonomy as "ability and willingness to help learners to take responsibility for their own learning. An autonomous teacher is thus a teacher who reflect on her teacher role, and who can change it, which can help their students become autonomous, and who can independent enough to let her learner become independent."

"The right of teachers to manage themselves and their job environment" (Pearson\&Hall,1993).This definition clears that autonomous teacher have freedom to deal with educational content and educational context autonomously in order to perform effectively. Shaw(2002) acknowledged that autonomy is "The capacity to take control of one's own teaching". It means autonomous teachers have ability or competence to regulate and direct their ideas. Little,(1995) stressed the same thought "Genuinely successful teacher have always been autonomous in the sense of having strong sense of personal responsibility for their teaching".

McGraft\& Aoki, (2002) further explained that autonomous teachers have capacity to teach without restrictions and responsibility to make choices concerning one's own teaching. Huang, (2005) approved the definition of autonomy given by McGraft\& Akoi and stated that Teacher autonomy is readiness, competence and independence to take control of their own teaching and learning. "The ability to develop appropriate skill, knowledge and attitude for oneself as a teacher in cooperation with other"

( Smith\&Erdu. 2008). According to Ling (2007) autonomy is "An insight, a positive attitude, capacity of reflective in teaching and readiness the learner to be more independent and to take control over his/her own teaching".

By all above definitions given by different researchers, it is clear that some components are common such as ability, capacity, willingness, independence cooperation and reflection to become self determined, socially responsible and critically aware member of educational environment. McGrath(2000) defined teacher autonomy in a comprehensive way and mentioned two discrete dimensions viz. (i) As self directed professional development and(ii) as freedom of control from others. The first dimension is more concern about psychological perspective and second is related to political perspective.

\section{THEORETICAL FRAMEWORK OF TEACHER AUTONOMY Self-determination theory (Deci\& Ryan,2006)}

According to Deci and Ryan(2006) autonomy is a state of an individual's self-directing and selfregulating activities in which he experiences positive freedom which is essential for satisfaction (Berofsky 1995). Self-determination is a condition in which individual feel freedom in his/her choice of actions and behavior and act independently from external environment (Deci and Ryan,2006).Ryan \&ConnelI(1989) suggested five types of perceived motivation :

- External motivation

- Introjections motivation

- Identified motivation

- Integrated motivation and

- Intrinsic motivation

The intrinsic motivation provides inherent satisfaction and considered as autonomous motivation. It satisfied all three innate psychological needs namely autonomy, competence and relatedness(Deci\&Ryan, 2000) and regard as process of internalization and a sense of personal and professional empowerment(Little at el 2002). When we discuss autonomy in the context of teaching it is seen that teacher motivation, job satisfaction, burnout, professionalism and empowerment are closely associated with each other (Pearson \&Moomow, 2005).

Gavrilyuk (2012) presented a conceptual model for prompting perceived autonomy. This model shows that intrinsic motivation to personal and 
professional development, personality attributes (Internal locust of control, responsibility, \&creativity) and competencies (ability of setting goal, decision making, ability to make choices \& minded fullness) are essential requirements for dealing educational challenges positively and effectively(Gavrilyuk, 2012). Perceived autonomy is teacher generic competency determined by intrinsic motivation to personal and professional development, creativity, free from external factors, effective performance in different educational setting.

Autonomy is a trait of a person related to whole personality not in one particular act and display in all aspects of lives as a whole. Autonomous person knows how and when to perform the activity (Sarata, 1984) and has full responsibility of their actions.(Gavrilyuk,2012).According to G.P.Sarapking (2004) development of autonomy should be the top target of teacher education process in order to develop professional socialization. Teacher autonomy is power \&ability to perform self-directing and self-governing teaching- learning activities and freedom for their professional development (Kamii,2000). Smith (2001) gave the inclusive definition of teacher autonomy as "the ability to develop appropriate skills, knowledge and attitudes for oneself as a teacher, in cooperation with others."

Little (1995) defined teacher autonomy as selfdirected teaching leading to control of teachinglearning process. Benson (2000) argued teacher autonomy as "right of freedom from control". Naoko Akoi (2000) defined teacher autonomy as "The capacity (pedagogical skills), freedom (from control) and responsibility to make choices concerning one's own teaching.

In the literature, there has been an increasing attention given to teacher autonomy (McGrath, Sinclair, \& Lamb, 2000; Lamb \&Reinders, 2008). Teacher autonomy has been defined as the ability to improve one's own teaching through one's own efforts ( Lamb\&Reinders, 2008). It therefore includes both the teacher's ability to make decisions about teaching and their own professional development. This assumes both a degree of political autonomy in the sense that teachers need to have the freedom to make such decisions, as well as knowledge of themselves as teachers and as learners, in order to know how to make such decisions. Teacher autonomy is also usually conceived as the ability to understand the students' learning needs and the ability to support them in their development towards autonomy. McGrath (2000) explained the teacher autonomy on the bases of two dimensions i.e. Self-directed actions/development and freedom of control by others. In order to understand the psychometric property of teacher autonomy, a sound measure is required (Wilsom(1993). To examine teacher autonomy, various tools were developed by many researchers such as Charters(1974), Gnecco(1983)and Pearson and Hall(1993). Pearson and Moomaw (2006) verified the teacher autonomy scale (TAS) developed by pearson and Hall(1993). A conformatory analysis(LISREL) was done and this study supported the factors such as teaching autonomy and curriculum autonomy .

It is widely acknowledged that autonomy is essential to develop self-esteem and self-confidence, and considered as regular and ongoing process of selfdiscovery. The prime goal of education is to develop the autonomous way of thinking among students to execute their task independently by making correct decisions in real life situations, to deal with the environment and to solve the problems they face in everyday situations.(Association of career and technical education consortium and partnership $21^{\text {st }}$ century skills 2010). The culture and education is the two sides of same coin or connected with each other. The techniques, strategies and methods suitable in one cultural setting or context may not be fit in another setting. Hence, the culturally sensitivity is a fundamental feature of a teacher or teacher educators. NCF (2005) declared that "teacher autonomy is essential for ensuring the learning environment that addresses student's diverse need". NCFTE (2009)also acknowledged that knowledge is not given it should be produced by reflection, innovation and creativity. It is need of the hour that academic freedom should be provided to the teacher educators who are engaged in imparting knowledge to the pre-service as well as inservice teachers.

The present paper is intended to know the Autonomy of teacher educators for their gender, type of institutions and subject of teaching.

\section{OBJECTIVES OF THE STUDY}

1. To know the difference in Autonomy of teacher educators working in B.Ed. institutions of Delhi with respect to the type of institutions.

2. To study the Autonomy of teacher educators working in B.Ed. institutions of Delhi with respect to their gender.

3. To study the Autonomy of teacher educators working in B.Ed. institutions of Delhi with respect to their subject of Teaching.

\section{HYPOTHESES OF THE STUDY}

1. There is no significant difference in Autonomy among teacher educators with respect to their type of institutions. 
2. There is no significant difference in Autonomy among teacher educators with respect to their gender.

3. There is no significant difference in Autonomy among teacher educators with respect to their subject of Teaching.

\section{OPERATIONAL DEFINITION}

Teacher Educator Autonomy refers to the freedom and power of the teacher educators to make independent decisions regarding teaching, curriculum and for their professional development.

\section{DELIMITATION OF THE STUDY}

1. The study limited to the B.Ed. institutions of Delhi.

\section{METHODOLOGY OF THE STUDY}

This study was descriptive in nature. The investigator has used survey method for describing and investigating the existing phenomenon.

\section{POPULATION AND SAMPLE OF THE STUDY}

The population of the present study comprises all the teacher educators working in Government aided and Self-financed B.Ed. institutions of Delhi. 100 Teacher Educators were taken as sample by stratified sampling technique.

\section{TOOL OF THE STUDY}

Teacher educator's autonomy scale (TAS) adapted from Pearson and Moomaw (2006) scale has been used to measure the autonomy of teacher educators which has 22 statements distributed in three dimensions such as-1. Teacher Autonomy. 2.Curricular Autonomy and 3. Professional development Autonomy.

\section{TECHNIQUES OF DATA ANALYSIS}

The researcher used Mean, Standard deviation, t-test and graphs for analyzing the data.

Collection of data and scoring:

To collect the data, first of all the permission has taken from concerned authority and then instructions have clearly explained to the teacher educators regarding Autonomy scale. After collecting all questionnaires (100), the investigator has given the scores. For the positive items, direct scoring method was used i.e.3-2-1, in case of negative items reverse scoring method was used i.e.1-2-3. All the scores has added against each item to get total score .

\section{RESULTS AND INTERPRETATION}

Objective 1: To find out the difference in autonomy among teacher educators for their type of institutions.

Hypothesis 1 : There is no significant difference in level of autonomy among teacher educators for their type of institutions.

Table 1: Comparison on dimensions of Autonomy of teacher educators for their type of institutions:

\begin{tabular}{|c|c|c|c|c|c|c|c|}
\hline \multirow[t]{2}{*}{ S. No. } & \multirow[t]{2}{*}{ Dimensions } & \multicolumn{2}{|c|}{ Govt. aided } & \multicolumn{2}{|c|}{ Self-financed } & \multirow[t]{2}{*}{ 't' value } & \multirow[t]{2}{*}{ Result } \\
\hline & & Mean & S.D. & Mean & S.D. & & \\
\hline 1. & Teaching Autonomy & 31 & 2.9 & 28.1 & 3.2 & $4.71^{*}$ & 0 \\
\hline 2. & Curriculum Autonomy & 14.8 & 1.95 & 14.1 & 1.96 & 1.64 & NS \\
\hline 3. & $\begin{array}{l}\text { Professional development } \\
\text { Autonomy }\end{array}$ & 10.2 & 1.53 & 8.8 & 1.68 & $2.63^{*}$ & 0.01 \\
\hline
\end{tabular}

*significant at 0.01 level, NS not significant 


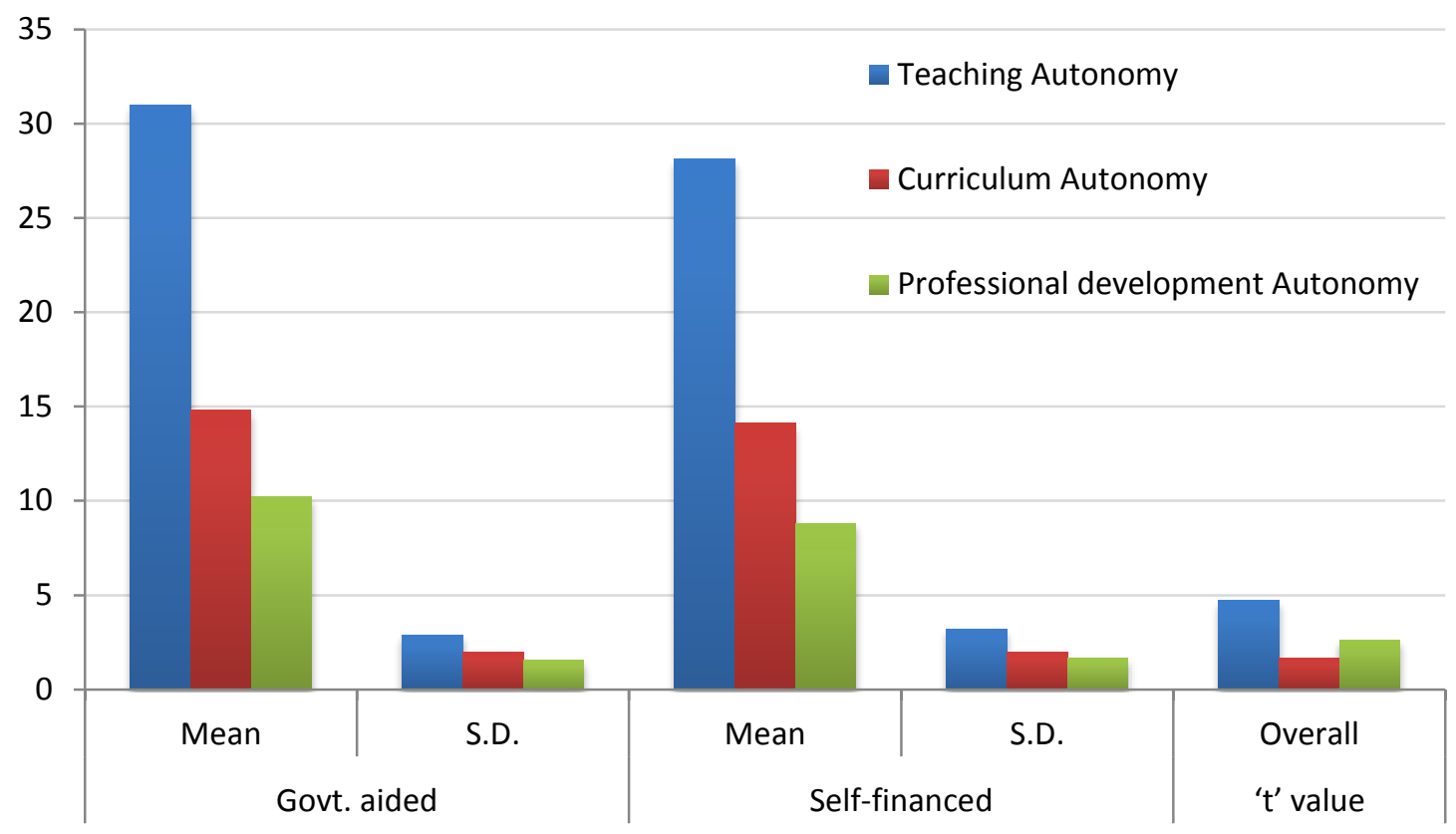

Fig 1: Histograms representing the statistical metrics for dimensions of Autonomy of teacher educators for their type of institutions

\section{Interpretation}

Teaching Autonomy-In order to compare the teacher educators working in Govt. aided B.Ed. institutions and self-financed institutions on the dimensions of teaching autonomy, mean, $\mathrm{SD}$ and ' $\mathrm{t}$ ' test was used to find if there exist any significant difference between the two groups. It is clear from table 1 and figure 1 that mean and standard deviation of teacher educators working in Govt. aided B.Ed. institutions are 31.0 and 2.9 respectively and teacher educators working in selffinanced B.Ed. institutions are 28.1 and 3.2 respectively. The t-ratio of mean is 4.71 which is highly significant and indicate that there is statically significant difference between the two groups of respondents and hence the null hypothesis that "there is no significant difference in the teaching autonomy of teacher educators working in different types of B.Ed. institutions" is rejected. The result shows that difference is statically significant Therefore it can be said that the Govt. aided B.Ed. institutions are providing more professional independence in teaching than self-financed B.Ed. institutions.

Curriculum Autonomy-In order to compare the teacher educators working in Govt. aided B.Ed. institutions and self-financed institutions on the dimensions of curriculum autonomy, mean, SD and ' $t$ ' test was used to find if there exist any significant difference between the two groups. It is clear from table 1 and figure1 that mean and standard deviation of teacher educators working in Govt. aided B.Ed. institutions are 14.8 and 1.95 respectively and teacher educators working in self-financed B.Ed. institutions are 14.1 and 1.96 respectively. The t-ratio of mean is 1.64 which is not significant at 0.05 and indicates that there is no statically significant difference was found between the two groups of respondents and hence the null hypothesis that "there is no significant difference in the curriculum autonomy of teacher educators working in different types of B.Ed. institutions" is accepted. The result shows that difference is not statically significant Therefore, it can be said that both types of institutions are following prescribed curriculum by the authorities or management.

Professional development Autonomy-In order to compare the teacher educators working in Govt. aided B.Ed. institutions and self-financed institutions on the dimensions of professional development autonomy, mean, SD and ' $t$ ' test was used to find if there exist any significant difference between the two groups. It is clear from table 1and figure1 that mean and standard deviation of teacher educators working in Govt. aided B.Ed. institutions are 10.2 and 1.53 respectively and teacher educators working in self-financed B.Ed. institutions are 8.8 and 1.68 respectively. The t-ratio of mean is 2.63 which is significant at 0.01 and indicate that there is statically significant difference between the 
two groups of respondents and hence the null hypothesis that "there is no significant difference in the professional development autonomy of teacher educators working in different types of B.Ed. institutions" is rejected. The result shows that difference is statically significant Therefore, it can be said that teacher educators working in Govt. aided B.Ed. institutions have more autonomy for their professional development as compared to teacher educators working in self-financed B.Ed. institutions.
Objective 2: To find out the difference in autonomy among teacher educators for their Gender.

Hypothesis 2: There is no significant difference in level of autonomy among teacher educators for their gender.

In order to test null hypothesis that there is no significant difference in autonomy of teacher educators for gender, the mean, SD of the two groups was calculated and t-value was calculated as shown in table2

Table 2: Comparison on dimensions Autonomy of teacher educators with respect to their gender (28 male and 72 female)

\begin{tabular}{|l|l|l|l|l|l|l|l|}
\hline \multirow{2}{*}{ S.No. } & \multirow{2}{*}{ Dimensions } & \multicolumn{2}{|c|}{ Male } & \multicolumn{2}{c|}{ Female } & \multirow{2}{*}{} & \multirow{2}{*}{} \\
\cline { 3 - 7 } & & Mean & S.D. & Mean & \multicolumn{1}{c|}{ S.D. } & 't' value & Result \\
\hline 1. & Teaching Autonomy & 27.0 & 3.7 & 28.1 & 3.3 & -1.3 & NS \\
\hline 2. & Curriculum Autonomy & 13.0 & 2.1 & 13.3 & 1.9 & -0.39 & NS \\
\hline 3. & $\begin{array}{l}\text { Professional development } \\
\text { Autonomy }\end{array}$ & 9.9 & 1.3 & 10.1 & & -0.77 & NS \\
\hline
\end{tabular}

NS = Not significant

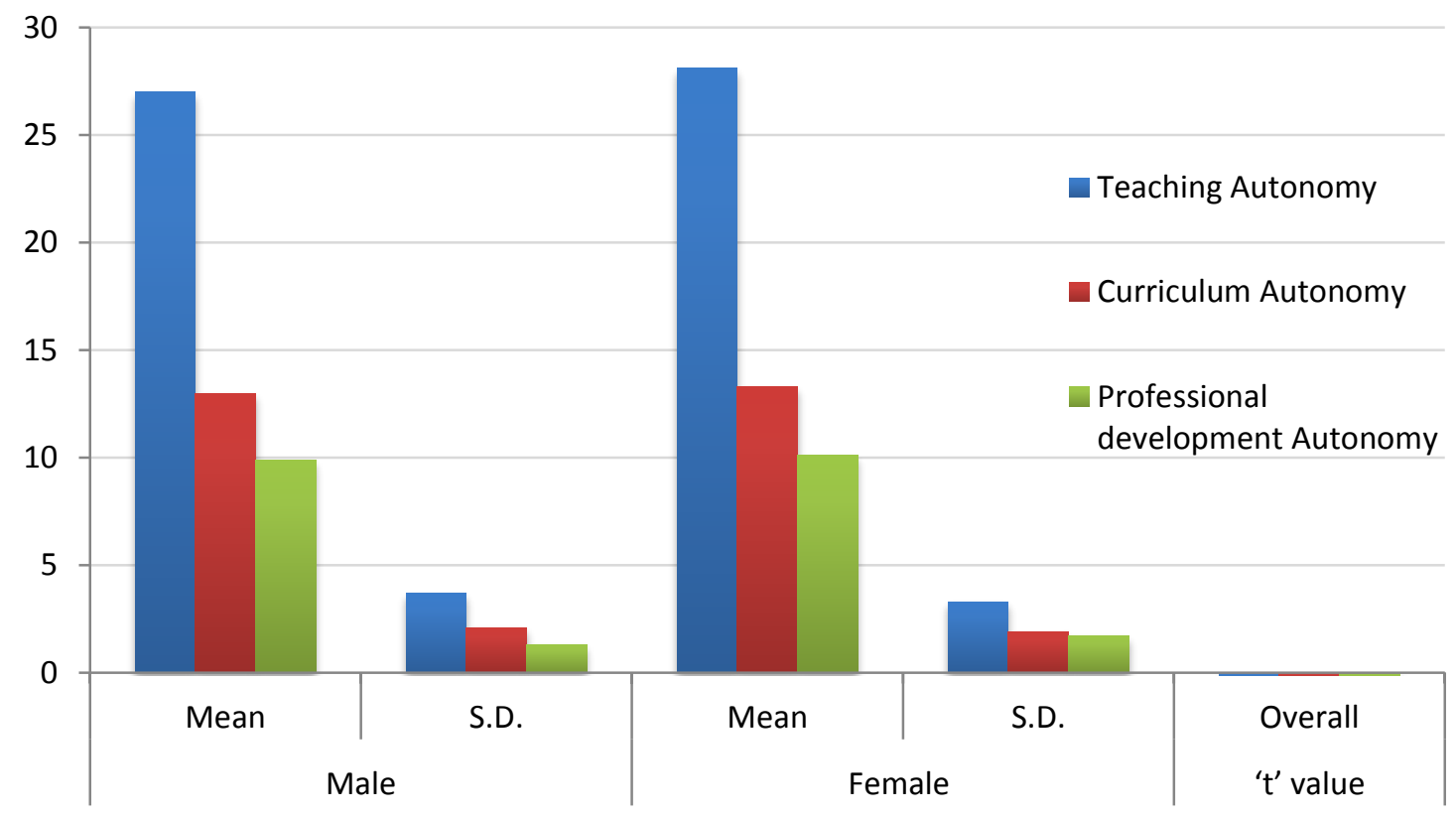

Fig 2: Histograms representing the statistical metrics for Dimensions Autonomy of teacher educators with respect to their gender

\section{Interpretation}

Teaching Autonomy- In order to see the difference between the male and female teacher educators on the dimensions of teaching autonomy, Mean and standard deviation was calculated and ' $\mathrm{t}$ ' test was used to find out that there exist any significant difference. It is clear from the table 2 and figure 2 that mean value of score for male teacher educators $(\mathrm{M} 1=27.0)$ and for female 
teacher educators $(\mathrm{M} 2=28.1)$. The value of ' $\mathrm{t}$ ' was found to be 1.3 which is not significant and suggest that there is no statically significant difference between male and female teacher educators with respect to their teaching autonomy. Both the groups of male and female teacher educators are similar on teaching autonomy. It means both the group of teacher educators have similar control over their teaching practice such as selection of teaching methods, strategies and student learning activities.

Curriculum Autonomy-In order to see the difference between the male and female teacher educators on the dimensions of curriculum autonomy, Mean and standard deviation was calculated and ' $t$ ' test was used to find out that there exist any significant difference. It is clear from the table 2 and figure 2 that mean value of score for male teacher educators $(\mathrm{M} 1=13.0)$ and for female teacher educators $(M 2=13.3)$. The value of ' $t$ ' was found to be 0.39 which is not significant and suggest that there is no statically significant difference between male and female teacher educators for their curriculum autonomy. Both the groups of male and female teacher educators are similar on curriculum autonomy. It means both the group of teacher educators have similar control over the content to be taught in the class such as selection of teaching materials and skills. Professional development Autonomy-In order to see the difference between the male and female teacher educators on the dimensions of professional development autonomy, Mean and standard deviation was calculated and ' $t$ ' test was used to find out that there exist any significant difference. It is clear from the table 2 and figure 2 that mean value of score for male teacher educators $(M 1=9.9)$ and for female teacher educators $(\mathrm{M} 2=10.1)$. The value of ' $\mathrm{t}$ ' was found to be 0.77 which is not significant and suggest that there is no statically significant difference between male and female teacher educators for their professional development autonomy. Both the groups of male and female teacher educators are similar on professional development autonomy. It means both the groups have similar kind of opportunities for their professional development to enrich knowledge by participating in conferences, workshops and faculty development programs.

Objective 2: To find out the difference in autonomy among teacher educators for their Subject of Teaching.

Hypothesis 2: There is no significant difference in level of autonomy among teacher educators for their Subject of Teaching.

In order to test null hypothesis that there is no significant difference in autonomy of teacher educators for Subject of Teaching, the mean, SD of the two groups was calculated and t-value was calculated as shown in table3

Table 3: Comparison on dimensions Autonomy of teacher educators for their teaching subjects

\begin{tabular}{|c|c|c|c|c|c|c|c|}
\hline \multirow[t]{2}{*}{ S.No. } & \multirow[t]{2}{*}{ Dimensions } & \multicolumn{2}{|c|}{ Science subjects } & \multicolumn{2}{|c|}{$\begin{array}{ll}\begin{array}{l}\text { Non } \\
\text { subjects }\end{array} & \text { science } \\
\end{array}$} & \multirow[t]{2}{*}{$\begin{array}{l}\mathrm{t} \text { ' } \\
\text { value }\end{array}$} & \multirow[t]{2}{*}{ Result } \\
\hline & & Mean & S.D. & Mean & S.D. & & \\
\hline 1. & $\begin{array}{l}\text { Teaching } \\
\text { Autonomy }\end{array}$ & 29.6 & 3.6 & 28.8 & 3.3 & 1.2 & NS \\
\hline 2. & $\begin{array}{l}\text { Curriculum } \\
\text { Autonomy }\end{array}$ & 13.9 & 2.2 & 14.7 & 1.8 & $1.96^{*}$ & 0.05 \\
\hline 3. & $\begin{array}{l}\text { Professional } \\
\text { development } \\
\text { Autonomy }\end{array}$ & 10.1 & 1.8 & 9.9 & 1.5 & 0.67 & NS \\
\hline
\end{tabular}




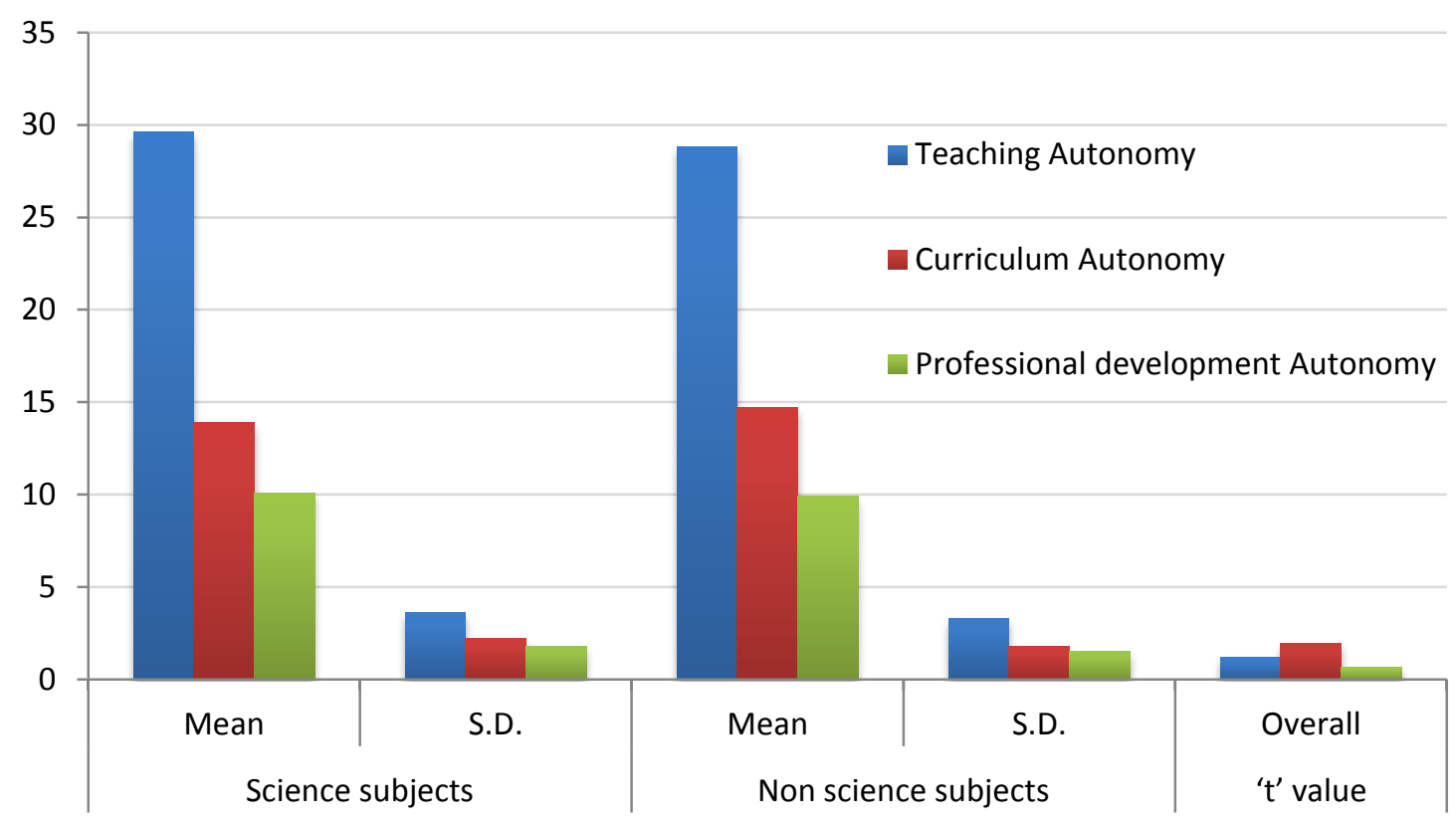

Fig 3: Histograms representing the statistical metrics for dimensions of Autonomy of teacher educators with respect to their type of institutions

\section{Interpretation}

Teaching Autonomy-In order to compare the teacher educators teaching science subjects and non science subjects on the dimensions of teaching autonomy, mean, SD and ' $t$ ' test was used to find if there exist any significant difference between the two groups. It is clear from table 3 and figure 3 that mean and standard deviation of teacher educators teaching science subjects are 29.6 and 3.6 respectively and teacher educators teaching non science subjects are 28.8 and 3.3 respectively. The t-ratio of mean is 1.2 which is not significant at 0.05 level of significance and indicates that there is no statically significant difference between the two groups of respondents and hence the null hypothesis that "there is no significant difference in the teaching autonomy of teacher educators teaching science subjects and non science subjects" is accepted. The result shows that difference is not statically significant Therefore it can be said that the teacher educators teaching science subjects have more teaching autonomy as compared to teacher educators teaching non science subjects but the difference is not statically significant.

Curriculum Autonomy-In order to compare the teacher educators teaching science subjects and non science subjects on the dimensions of curriculum autonomy, mean, $S D$ and ' $t$ ' test was used to find if there exist any significant difference between the two groups. It is clear from table 3 and figure 3 and figure 4.15 that mean and standard deviation of teacher educators teaching science subjects are 13.9 and 2.2 respectively and teacher educators teaching non science subjects are 14.7 and 1.8 respectively. The t-ratio of mean is 1.96 which is significant at 0.05 level of significance and indicates that there is statically significant difference between the two groups of respondents and hence the null hypothesis that "there is no significant difference in the curriculum autonomy of teacher educators teaching science subjects and non science subjects" is rejected. The result shows that difference is statically significant Therefore it can be said that the teacher educators teaching non-science subjects have more curriculum autonomy as compared to teacher educators teaching science subjects .

Professional development Autonomy-In order to compare the teacher educators teaching science subjects and non science subjects on the dimensions of professional development autonomy, mean, SD and ' $t$ ' test was used to find if there exist any significant difference between the two groups. It is clear from table 3 and figure 3 that mean and standard deviation of teacher educators teaching science subjects are 10.1 and 1.8 respectively and teacher educators teaching non science subjects are 9.9 and 1.5 respectively. The tratio of mean is 0.67 which is not significant at 0.05 and indicate that there is no statically significant 
difference between the two groups of respondents and hence the null hypothesis that "there is no significant difference in the professional development autonomy of teacher educators teaching science subjects and non science subjects" is accepted. The result shows that difference is not statically significant Therefore it can be said that the teacher educators teaching science subjects have more professional development autonomy as compared to teacher educators teaching non science subjects but the difference is not statically significant.

Discussion: The findings showed that the teacher educators teaching in Govt. aided B.Ed. institutions found to have used more autonomy as compared to the teacher educators teaching in self-financed institutions. The findings supported by an article written by Rekha Choudhary. She also highlighted in her article that central universities provide better working environment to pursue their academic activities and their teachers are more autonomous. The state level universities teachers work under bureaucratic and controlled environment which make the teachers ineffective and un-autonomous. Due to bureaucratic environment of the state universities, power comes in the hand of administration and head of the institutions work as CEO of the company rather than academic leader.

The findings showed that there is no significant difference between the autonomy of teacher educators with respect to gender. The findings are similar with the result found in study conducted by Singh, $\mathrm{S}$, Chabra,S,\&Chopra,v(2015) and Beri. N \&Beri. A (2016) in which they found out that there was no significant difference between male and female teacher educators for their professional commitment.

A significant difference was found between Teacher educators of teaching science and non-science subjects in case of curriculum autonomy. The teacher educators teaching non-science subjects are found to have more autonomy than teacher educators teaching science subjects. It shows that more flexible curriculum is adopted in case of non-science subjects.

\section{CONCLUSION}

The present study is an attempt to explore the Autonomy of teacher educators working in different types B.Ed. colleges in Delhi. The following conclusions were drawn from the finding-

There is statically high significant difference was found between the teacher educators of Govt. aided and Self-financed B.Ed. institutions of Delhi. It can be said that teacher educators working in Govt. aided B.Ed. institutions have better Autonomy as compared to self-financed B.Ed. institutions with respect to its all dimensions.

There is statically no significant difference was found in Autonomy of teacher educators between male and female B.Ed. institutions of Delhi with respect to its all dimensions.

There is statically no significant difference was found in Autonomy of teacher educators between teacher educators teaching science and non-science subjects with respect to teaching autonomy and professional development Autonomy but in case of curriculum autonomy significant difference was found. It shows that non-teaching subjects are teaching with flexible curriculum.

\section{REFERENCES}

1. Anita Devi (2011). A Comparative study of teacher educators of Govt. aided and self-financed college of education in relation to their professional value, teaching aptitude \&job satisfaction. Retrieved from https://shodhganga.inflibnet.ac.in/handle/10603/20 $\underline{7486}$.

2. Best, J. W., \& Khan, J. (1993). Research in education7th edition. New Jersey: Prentice Hall.

3. Bhatnagar, R. P. (2007). Reading in Methodology of Research in Education; R. Lall Book Depot, Meerut.

4. Cakir, A. (2012). The use of the EPOSTL to foster teacher autonomy: ELT student teachers' and teacher trainers' views. Australian Journal of Teacher Education, 37(3), 2.

5. Cheon, S. H., Reeve, J., Lee, Y., \& Lee, J. W. (2018). Why autonomy-supportive interventions work: Explaining the professional development of teachers' motivating style. Teaching and Teacher Education, 69, 43-51.

6. Deci, E. L., \& Ryan, R. M. (2012). Selfdetermination. The Corsini encyclopedia of psychology, 1-2.

7. Diyan, R. O., \& Adediwura, A. A. (2016). Development of a rating scale for measuring teacher classroom autonomy in secondary schools in South-Western Nigeria. International Journal of Education and Practice, 4(4), 134-147.

8. Federici, R. A. (2013). Principals' self-efficacy: Relations with job autonomy, job satisfaction, and contextual constraints. European journal of psychology of education, 28(1), 73-86.

9. Indu Nain (2016). Role conflict, commitment and life satisfaction of teacher educators in relation to their academic steams, type of institutions and locust of control. Retrieved from https://shodhganga.inflibnet.ac.in/handle/10603/20 $\underline{7486 .}$

10. Gandhimathi, S.N.S. and Anitha Devi, V. (2015). 'Enhancing learner autonomy by integrating technology among engineering learners Retrieved from 
11. Gavrilyuk.O.A(2013). Understanding University Teacher Autonomy as a Mainspring of Reforming Higher Education. Journal of Siberian Federal University. Humanities \& Social Sciences. $12(2013$ 6) $1800-1815$.

12. Iwata, T. (2013). Teacher's autonomy and students' creativity (Doctoral dissertation, University of Georgia).

13. Malik, A. R. (2019). PROFESSIONAL COMMITMENT OF GOVERNMENT AND PRIVATE PHYSICAL EDUCATION TEACHERS WITH SPECIAL REFERENCES TO THEIR GENDER. Journal Current Science, 20(06).

14. Mezirow, J. (1993). A transformation theory of adult learning. In Adult Education Research Annual Conference Proceedings (Vol. 31, pp. 141146).

15. NCF(2005). NCERT. https://ncert.nic.in/pdf/ncframework/nf2005-english.pdf

16. NCFTE(2009).NCTE. https://ncte.gov.in/website/PDF/NCFTE_2009.pdf

17. Pearson, L. C., \& Hall, B. W. (1993). Initial construct validation of the teaching autonomy scale. The Journal of Educational Research, 86(3), 172-178.

18. Pearson, L. C., \& Moomaw, W. (2005). The relationship between teacher autonomy and stress, work satisfaction, empowerment, and professionalism. Educational research quarterly, 29(1), 38-54.

19. Ramos, R. C. (2006). Considerations on the role of teacher autonomy. Colombian Applied Linguistics Journal, 183-202.

20. Rani, R. (2019). Professional commitment among teacher educators. BHARTIYAM INTERNATIONAL JOURNAL OF EDUCATION \& RESEARCH, 9 (I).

21. Sahito, Z., \& Vaisanen, P. (2017). Factors Affecting Job Satisfaction of Teacher Educators: Empirical Evidence from the Universities of Sindh Province of Pakistan.Journal of Teacher Education and Educators, 6(1), 5-30.

22. Sehrawat, J. (2014). Teacher autonomy: Key to teaching success. HARTIYAM INTERNATIONAL JOURNAL OF EDUCATION \& RESEARCHA: quarterly peer reviewed International Journal of Research\& Education, Volume4, (1), 2277-1255.

23. Sharma, $\boldsymbol{S}$ (2016). A comparison of professional commitment of low age group (Below 30 years), average age group (30-45 years) and high age group (Above 45 years) of teacher educators belonging to Panjab University, Chandigarh, Indian journal of applied research,

24. Ulas, J., \& Aksu, M. (2015). Development of teacher autonomy scale for Turkish teachers. Procedia-Social and Behavioral Sciences, 186, 344-349. 